
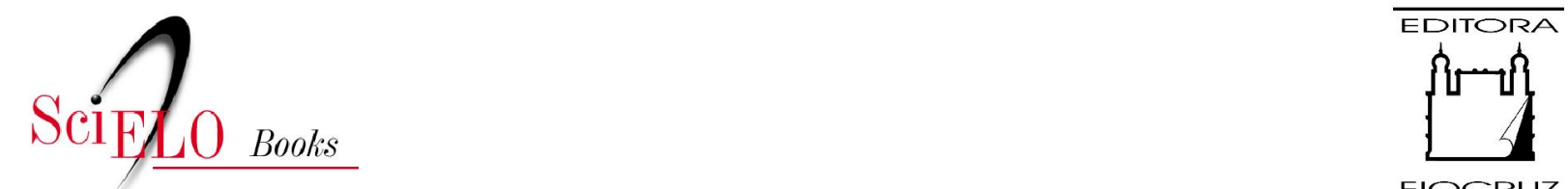

FIOCRUZ

\title{
2. Identidade, diferença e exclusão na Sociedade brasileira contemporânea
}

\author{
Benilton Bezerra Jr
}

\section{SciELO Books / SciELO Livros / SciELO Libros}

BEZERRA JR, B. Identidade, diferença e exclusão na Sociedade brasileira contemporânea. In:

ACSELRAD, G. org. Avessos do prazer: drogas, Aids e direitos humanos [online]. 2nd ed. rev. and enl. Rio de Janeiro: Editora FIOCRUZ, 2005, pp. 35-50. ISBN: 978-85-7541-536-8. Available from: doi: $10.7476 / 9788575415368$. Also available in ePUB from: $\underline{\text { http://books.scielo.org/id/bgqvf/epub/acselrad-9788575415368.epub }}$

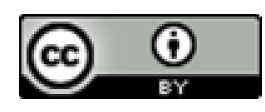

All the contents of this work, except where otherwise noted, is licensed under a Creative Commons Attribution $\underline{4.0 \text { International license. }}$

Todo o conteúdo deste trabalho, exceto quando houver ressalva, é publicado sob a licença Creative Commons Atribição 4.0.

Todo el contenido de esta obra, excepto donde se indique lo contrario, está bajo licencia de la licencia Creative Commons Reconocimento 4.0 . 


\title{
IDENTIDADE, DifERENÇA E EXCLUSÃO NA SOCIEDADE BRASILEIRA CONTEMPORÃNEA
}

\author{
Benilton Begerra gr
}

\section{Uma Atmosfera de Crise}

Tornou-se lugar comum, hoje em dia, falar de crise. Ela parece estar em toda parte. Crises políticas crônicas, como as do Oriente Médio e da África, e crises agudas, como aquelas que nos últimos anos vêm explodindo de maneira surpreendente entre as populações e governos dos países balcânicos. Crises econômicas: com a globalização, todo o planeta passou a viver em sobressalto permanente. A qualquer momento, e de surpresa - para os desavisados -, países que, na semana anterior, pareciam ostentar uma economia exemplar subitamente ameaçam ir à bancarrota, levando junto com eles dezenas de outros países e centenas de milhões de pessoas. A atmosfera de crise não atinge apenas países e economias. Nem mesmo a natureza está a salvo: os efeitos provocados por agressões maciças ao meio ambiente produzem um impacto cada vez mais global e profundo no equilíbrio ecológico do planeta. Há um sentimento universal crescente de que os recursos naturais de que a espécie dispõe estão efetivamente começando a escassear.

No plano da cultura, a crítica feroz aos desmazelos da racionalidade totalizante e imperativa, tão comum nos últimos tempos, tem vindo freqüentemente acompanhada de uma espécie de celebração do fugaz, do efêmero, da virtualidade e do provisório, que tem como efeito colateral uma atmosfera de incerteza e insegurança em relação do futuro. A tudo isso é preciso acrescentar a rápida desorganização - no período pós-guerra fria - dos quadros de referência política e social que durante os últimos cem anos organizaram o mundo em projetos universais. O bipolarismo geopolítico trazia para o cotidiano uma competição entre alternativas que visavam não só ao cenário atual, mas sobretudo à construção de uma hegemonia no futuro. 
O confronto existia, é claro, mas a crise sempre podia ser atribuída ao outro lado. Com a queda do muro de Berlim, desabou esse quadro e, com ele, o pano de fundo que, de um jeito ou de outro, ajudava a organizar o sentido da história na qual estávamos inseridos. Sem ele, os indivíduos têm maior dificuldade de compreender os interesses e a direção dos conflitos e disputas, perdendo-se na impressão de que a lógica dos acontecimentos lhes escapa. No plano da vida subjetiva tudo isso não deixa de produzir efeitos. Entre outros, uma experiência de si cada vez mais marcada pelo sentimento de superficialidade, pela fragmentação das imagens identitárias, pela apatia psíquica, pela tensão entre a sofreguidão consumista, de um lado, e a tonalidade vagamente depressiva no cotidiano, por outro.

Mais do que um conjunto de crises particulares, poderíamos falar de um sentimento disseminado de crise, que afeta o imaginário social de maneira contundente e destrutiva, diminuindo drasticamente a capacidade de construir promessas de um mundo melhor projetadas em um futuro ao alcance de nossas ações. Esse efeito é perceptível tanto no nível individual quanto no nível coletivo e diz respeito à perda - no plano da experiência vivida - da dimensão de historicidade no seu sentido forte, ou seja, da assunção da responsabilidade quanto ao futuro. É como se ele já não dependesse tanto de nossas ações no presente. Diante de uma realidade adversa e cheia de incertezas, parece não haver outra saída para os sujeitos, exceto a expressão de uma indignação impotente, ou a busca de estratégias de sobrevivência que dêem conta do imediato.

$\mathrm{Na}$ realidade, nunca deixou de haver crises ao longo da história humana: rupturas, mudanças violentas, períodos de grande turbulências. A história é feita de transformações, e - como disse Lenin com razão - a violência é muitas vezes a parteira da história. O que há de particular em relação ao que estamos vivendo, porém, é que o sentido das transformações parece nos escapar, parece seguir uma lógica da qual não conseguimos nos apropriar e que nos governará quer queiramos, quer não. Nos períodos anteriores à época moderna no Ocidente, essa não era uma experiência corrente. O sentido geral da história se expressava em utopias religiosas, que organizavam simbolicamente o reino material e humano, tornando plausíveis, para os homens, os seus destinos. Com a modernidade, a crença em uma Razão universal tomou o lugar hegemônico da religião. As revoluções modernas, como a americana e a francesa, trouxeram o sentido da história para o âmbito de ação dos homens. Pela primeira vez, a humanidade ousava decidir que tipo de sociedade construir, a partir de valores que - embora universais - eram terrenos. 
A utopia moderna de uma sociedade democrática - feita por e para seres humanos livres, iguais e solidários - fundou-se na vontade de construir um mundo melhor para todos e na convicção de que o destino pertence aos humanos e não aos deuses. Era isso que tornava o progresso possível: a crença na capacidade humana de recusar o presente em nome de um futuro mais desejável. Em outras palavras: sempre houve, mesmo nos períodos de maior arbítrio e violência, e no interior de organizações sociais injustas e desiguais, a possibilidade de vislumbrar uma alternativa, de pensar o presente indesejado como transitório e superável.

$\mathrm{O}$ que hoje parece diluir-se na atual experiência cotidiana da crise é justamente essa dimensão de historicidade, de potência em direção ao novo, de inquietação ativa e confiante em relação a um estado de coisas que se pretende mudar. O imaginário social contemporâneo parece impregnado de uma visão do mundo e dos sujeitos inteiramente regidos por instâncias heterônomas (Castoriadis, 1982), que esvaziam seu poder normativo, ou seja, sua capacidade de criar novas normas de funcionamento para si e para a sociedade. Diante das forças invisíveis e abstratas da economia, da inevitabilidade orgânica e concreta dos genes e hormônios, ou das estruturas inescapáveis do psiquismo, pouco resta para a ação, para a invenção. No final, parecemos todos condenados a fazer na vida pouco mais do que uma figuração discreta em uma peça cujo roteiro nos é imposto e cuja razão de ser nos escapa.

\section{O Mercado no lugar da Sociedade}

Entre as muitas conseqüências deste quadro, duas merecem destaque aqui: a primeira é a deterioração a que vêm sendo submetidos os valores da solidariedade e da tolerância para com a diferença e os diferentes nos dias atuais; a segunda é a decrescente estabilidade e confiabilidade de laços sociais tradicionalmente apaziguadores das identidades e propiciadoras de um terreno psicológico menos movediço para os indivíduos.

Os exemplos da primeira conseqüência são abundantes: a explosão de conflitos étnicos e religiosos nos países do antigo bloco socialista, o aumento assustador do racismo e da xenofobia na Europa Ocidental, a ascensão do fundamentalismo mais obscurantista em países muçulmanos, a dilaceração interna em ex-colônias africanas. A diluição de horizontes coletivos, o esmaecimento do poder normativo de valores universais e a necessidade de pertencimento que inevitavelmente surge como um remédio para angústia 
em um universo fragmentado, tudo isso contribui decisivamente para reforçar a adesão crescente a esses tipos de movimentos sociais. Este fenômeno é certamente complexo demais para ser analisado em poucas linhas. Mas vale a pena chamar a atenção para um dos elementos presentes na composição do quadro mais geral em que tudo isso acontece. Nos últimos 20 anos estamos vivendo um período marcado pela hegemonia crescente no plano político e econômico do que se convencionou chamar de neoliberalismo. O ano de 1989 marca simbolicamente o momento em que se concretizou finalmente essa hegemonia, após décadas de embate com as experiências inspiradas nas propostas socialistas e socialdemocráticas. Os equívocos do chamado socialismo real são conhecidos: a idéia de uma sociedade organizada de forma absolutamente racional, central e planificada como passo para a construção de maior justiça e fraternidade social mostrou seus limites e graves defeitos. Dependia de uma crença quase ilimitada (e muito pouco razoável) em uma racionalidade econômica e política que supostamente vislumbraria os meios para reorganizar a sociedade, de modo a superar definitivamente suas divisões e conflitos internos. As conquistas e acertos alcançados em certas áreas não supriram o que muitos críticos de orientação socialista há muito haviam apontado: a ausência de um processo efetivo de construção de espaços democráticos, o que resultou na burocratização de efeito letal (Castoriadis, 1983).

Apesar de tudo isso, é inegável que a dissolução de um mundo organizado basicamente em torno de dois pólos que disputavam hegemonia em todos os campos (político, econômico, ideológico) mudou drasticamente o cenário político mundial. Sem o campo de tensões organizado em torno do bipolarismo, as experiências socialdemocráticas da Europa, que historicamente significavam a tentativa de corrigir politicamente os efeitos cegos de uma economia liberal, viram desaparecer o chão debaixo dos pés e se tornaram vulneráveis às investidas neoliberais. Países periféricos, cujo apoio estratégico era valorizado nos tempos da guerra fria, tornaram-se supérfluos geopoliticamente e foram deixados de lado, entregues à própria sorte (Que sinos dobraram pela tragédia de tutsis e hutus ou da Libéria?). O planeta passou a ser globalmente submetido a uma lógica econômica que dispensa justificativas políticas, porque supostamente se baseia em uma racionalidade neutra. É como se a economia, fantasiada de ciência racional, tivesse conquistado supremacia total em relação à política, que passou a ser nada mais do que gestão de interesses econômicos e financeiros. $O$ que aconteceu não foi simplesmente o fato de a sociedade de mercado ter prevalecido sobre a economia planificada. É que agora a sociedade parece ser apenas e nada mais do que o mercado. E se até há pouco capitalistas e socialistas deba- 
tiam acerca do melhor caminho para promover o progresso humano e a conquista do futuro (nesse sentido a corrida ao espaço foi uma das mais belas metáforas), hoje em dia o vocabulário e os interesses mudaram. Trata-se de maior produtividade, menores custos, otimização dos investimentos, reengenharia, downsizing etc., que se supõe trarão como benefícios secundários mais riqueza global a ser distribuída para todos.

A realidade tem mostrado, no entanto, um quadro muito diferente. Ao lado de economias que sazonalmente ostentam índices aparentemente espantosos de crescimento, observa-se, nas populações desses mesmos países, o aumento do contingente de miseráveis. Paralelamente a uma expansão, sem precedentes na história, de tecnologias fantásticas em todos os campos, ressurgem com força total as doenças da pobreza e do passado. De um lado, presenciamos sem alarde um absurdo desperdício de energia e alimentos; do outro, uma foto, uma notícia rápida no jornal da noite nos jogam no rosto a realidade bárbara de crianças disputando com abutres restos de comida. Em um mundo que poderia alimentar a todos os seus habitantes, a morte por falta de comida é um destino provável para milhões. Vivemos em uma era de opulência, de um lado, e privação, por outro. Desperdício por parte de uns, carência absoluta por parte de outros. A competição, erigida em valor supremo, tem simplesmente deixado de lado todos aqueles que por diversos motivos se encontram - ou são jogados - à margem do todo-poderoso mercado (Kurtz, 1997).

\section{A ExcLusão dos IrRELEVAntes}

Um traço particularmente cruel, no entanto, caracteriza os novos tempos: o mundo do neoliberalismo criou um novo tipo de marginalização, mais radical e escandaloso do que aqueles com os quais sempre convivemos. É claro que toda organização social implica a existência do diferente, do oprimido, do marginalizado, do desigual. Toda cultura produz diferenças e sustenta alguma forma de hierarquia para ordená-las. Mesmo as sociedades igualitaristas da modernidade ocidental, fundadas no individualismo, abrigam estruturas hierarquizadas. Além disso, toda cultura implica normas. E toda norma implica o seu oposto, a 'antinorma', o desvio, a diferença. Uma sociedade que visasse à igualdade absoluta entre seus membros seria até mesmo indesejável; dificilmente poderia não ser uma forma qualquer de totalitarismo. Entretanto, até em sociedades profundamente desiguais pode haver laços de reciprocidade, ou seja, uma certa forma de organicidade que une os 
diferentes sob o manto de uma realidade maior que abarca a todos. Nas sociedades fortemente hierarquizadas como as sociedades de casta, por exemplo, é a religião que cumpre essa função de organizar simbolicamente as diferenças sociais (mesmo as mais brutais), e com isso dar a cada um lugar na totalidade social, um lugar de reconhecimento simbólico (Dumont, 1978, 1985). Na sociedades ocidentais tradicionais, apesar de não haver uma justificação teológica (pelo menos a partir do cristianismo) das diferenças entre opressores e oprimidos, exploradores e explorados, sempre houve uma 'necessidade social' dos estratos subordinados. Não poderia haver os homens livres da Grécia clássica sem os escravos e todos os demais privados da liberdade; não poderia haver a burguesia sem os operários e assim por diante. Desse modo, ao lado das diferenças e do tratamento desigual concedido a eles, sempre existiu um regime de distribuição de direitos e deveres e um mapeamento do lugar reservado a cada um no universo social.

Um dos elementos mais assustadores do quadro atual é que mesmo esse tipo de laço parece se desvanecer. Criou-se uma espécie de marginalização 'por obsolescência'. As políticas e mecanismos econômicos atuais vão simplesmente dispensando, para seu pleno funcionamento, a existência de contingentes imensos de seres humanos, que se tornaram literalmente supérfluos, desnecessários, obsoletos. O modelo neoliberal vigente implica a assunção de que o 'bolo' não é mesmo para todos. E como os seus opositores parecem ter sido calados para sempre, já não é mais preciso vender a idéia de que primeiro é preciso fazer o bolo crescer para só depois haver o que dividir. Quem puder arranjar convite, que entre na festa e dispute uma fatia; quem não puder, está mesmo barrado no baile e se transforma em descartável. No nível planetário, esse efeito perverso exclui nações inteiras, como acontece com boa parte dos países africanos. Até mesmo nas regiões ricas do chamado primeiro mundo o fenômeno é crescente. São milhões e milhões no mundo inteiro condenados a uma vida irrelevante. Não são sequer oprimidos ou explorados: não interessam, são deixados de lado. São verdadeiramente 'excluídos'.

As conseqüências desse quadro não podem passar despercebidas. Uma delas é que a reação espontânea dos excluídos tende a ser inteiramente despida de horizonte político, ao contrário do que caracterizou modernamente a luta dos que são postos à margem. Não se trata de criar espaços de liberdade, como nas revoltas de escravos, nem uma sociedade mais justa, como nos movimentos e revoluções operárias. Esses objetivos implicam a reivindicação de participação no conjunto social, com a finalidade de transformálo. A ação política exige sujeitos minimamente capazes de se reconhecerem 
como agentes, como capazes de estabelecer pactos coletivos com vistas à obtenção de objetivos comuns, como capazes de investir no presente as promessas do futuro, o seu ou de seus descendentes, e assim por diante (Arendt, 1981). Ora, a rarefação desses sentimentos é justamente um dos problemas mais sérios que enfrentam todos aqueles empenhados hoje em dia em mobilizar mesmo aqueles setores tradicionalmente engajados nos movimentos sociais. Para que qualquer indivíduo se sinta responsável pelos seus atos perante todos os demais membros de sua comunidade, é indispensável que ele se sinta necessário, que sua presença não seja irrelevante (Sennett, 1999). Quando isso deixa de acontecer, é a própria idéia de ação política que se encontra em processo de esvaziamento. E se isso é verdade para os que ainda se percebem como partes dos processos sociais de troca, é muito mais evidente nos contingentes excluídos. E o dramático é que, em um mundo em que as formas de reciprocidade, os laços de dependência necessária se tornam crescentemente inexistentes, mais do que nunca a solidariedade depende de uma opção ética e de uma ação política. Ou seja, é exatamente no momento em que as condições são menos propícias à formação de sujeitos e consciências coletivas dotadas de um desejo de futuro que mais precisamos da agência, da vontade, da determinação de mudar que só a expansão do espaço democrático e a construção do exercício da cidadania podem oferecer.

\section{CIDADANIA E IDENTIDADE}

Para fins desta discussão, podemos caracterizar, de modo um pouco impreciso (mas não equivocado), o projeto democrático como um processo de ampliação constante de espaços mais livres de coerção e a produção de mecanismos mais eficazes de promoção da solidariedade no interior da sociedade, com o objetivo de possibilitar, a um número cada vez maior de seus membros, a vida mais criativa e satisfatória possível.

Para entender melhor este ponto, importa fazer rapidamente menção a algumas idéias que dizem respeito à noção de identidade (analisada do ponto de vista da construção subjetiva, ou seja, dos processos pelos quais todo indivíduo se constitui como um sujeito dotado de uma imagem de si mais ou menos estável, base para sua ação no mundo).

Gostaríamos de insistir na idéia de que o projeto democrático só pode se tornar uma experiência real se levado a cabo por meio de seres humanos 
imbuídos da convicção de sua validade e armados não só com consciência racional de sua plausibilidade, mas também dotados de uma adesão afetiva, emocional ou subjetiva a esse projeto. Isto significa que não se pode pensar no processo de construção de cidadãos apenas como a fabricação social de agentes racionais orientados para a realização de certos objetivos universais e igualitários. É preciso também que esses agentes sejam dotados de um certo tipo de 'sentimentalidade', ou seja, sejam predominantemente regidos por uma pauta de reações afetivas ao mundo e aos seus semelhantes. E que contemplem, como alvo dessas respostas ao meio, a conquista de objetivos demarcados pelo chamado projeto democrático, em especial o exercício da solidariedade e da tolerância.

Essa afirmação, na realidade, nada tem de novo no seu núcleo. Os teóricos do contrato social já aludiam a ela, quando viam, na base de toda a vida social, um contrato estabelecido entre seus membros, que renunciam à concretização de certos interesses particulares com vistas à conquista de um mínimo de coesão que permita a realização de interesses comuns. Sem esse contrato, não seria possível a cooperação, a vida coletiva: ela seria destruída pela violência inerente a toda forma de vida, que se impõe de forma brutal para sobreviver. A cultura humana só existe porque essa violência é ordenada e administrada pelas regras e leis que compõem tal contrato. Certamente o excesso, a violência arbitrária, a crueldade estão presentes em qualquer forma de organização social. Mas em qualquer uma delas sempre há as regras que tornam tal ou qual tipo de violência aceitável ou intolerável. Entre nós, por exemplo, uma das regras básicas é a de que nenhum ser humano tem o direito de tirar a vida de um semelhante. Mas a regra, universal, tem suas exceções: nas guerras, por exemplo, o soldado não só tem permissão como obrigação de matar, obrigação que se não é cumprida o leva à corte marcial onde, então, é a sua própria existência que está em perigo. O juiz que condena alguém à cadeira elétrica o faz sob os auspícios da lei, e se alguém tira a vida do outro em legítima defesa, aceita-se o fato como defensável.

O equilíbrio social absoluto jamais é alcançado (exceto na ambição patológica dos regimes totalitários), mas a própria noção de uma contratualidade subjacente organiza as transgressões e as respostas a elas, ao mesmo tempo que fornece o chão do qual revoluções e rupturas emergem, instaurando novas ordens, novas normas de organização social. Também a psicanálise, desde seus primórdios, afirmou a existência de um pacto, de um acordo, na origem de todo laço social. Freud jamais renunciou à idéia de que a sociedade repousa sobre a coerção das pulsões. A renúncia à satisfação pulsional sem limites é indispensável tanto à vida subjetiva individual quanto à vida 
em sociedade. Sem essa renúncia o indivíduo se tornaria uma caricatura de animal selvagem. Caricatura porque, ao contrário daquele, o ser humano não vem ao mundo dotado de uma pauta inteiramente determinada de condutas para lidar com o meio ambiente. A força dos instintos nos animais é organizada em padrões de resposta ao meio que os orientam frente às necessidades e surpresas da vida. No ser humano essa força perde a direção precisa, o objeto naturalmente adequado. É preciso aprender a ser um humano, e o processo é demorado. Nenhum animal é tão dependente de outros de sua espécie quanto o homem.

Toda a extraordinária potencialidade incrustada na complexa e maravilhosa anatomia do cérebro não vem à tona sem a presença de outros indivíduos já socializados, que mergulham paulatinamente o recém-nascido no universo propriamente humano - o universo da cultura, da significação, da linguagem. É somente no interior desse universo que os recursos biológicos mais nobres do ser humano são despertados e acionados. Inscrever-se nesse universo implica ser atravessado pelas regras que o governam, regras que impõem a cada indivíduo limites, a começar pelas regras da própria linguagem - meio pelo qual o indivíduo humano se torna um sujeito, um 'eu'. Tornar-se um 'eu' significa, ao mesmo tempo, ser capaz de reconhecer os outros, perceber-se, assim como ocorre com os outros, regido por uma instância que transcende o singular, o particular, o idiossincrático: o simbólico, a cultura, ou as significações sociais e suas regras, que não são obra de nenhum 'eu' em particular e que, ao contrário, abarcam e marcam a todos sem exceção. Por outro lado, são os sujeitos que sustentam a permanência da cultura, dando-lhe suporte por meio da adesão e reprodução dos seus valores e instituições mais fundamentais. Mesmo quando rompem com esses valores, só o fazem para substituí-los por outros, por meio de novas significações gestadas na vida coletiva. Indivíduo e sociedade, portanto, são faces de uma mesma moeda (Castoriadis, 1999). A construção dos sujeitos individuais é sempre uma fabricação social e, por outro lado, qualquer sociedade só subsiste na medida em que encontre formas de se reproduzir por meio dos sujeitos que constrói.

\section{As EXIGÊNCIAS DO 'EU'}

Piera Aulagnier cunhou uma feliz expressão para dar conta desse processo de reciprocidade: "pacto narcísico". Assim ela denominou o processo pelo qual a cultura, em troca da própria sobrevivência, oferece a cada novo humano que emerge em seu seio um lugar de reconhecimento. Um lugar 
simbólico no qual o futuro sujeito ancorará seu processo de construção de si como um eu, de onde obterá o reconhecimento dos pares e a partir do qual processará - em um movimento que só termina com a morte - a pluralidade identificatória que se abriga sob seu nome próprio. Todo esse processo é realizado por meio da ação e da presença de humanos que o precedem na escala de gerações, humanos que representam simbolicamente a sociedade que acolhe o recém-chegado e que dão provas (libidinais) do desejo de integrá-lo ao todo social. Por outro lado, o sujeito, assim dotado de uma carga simbólica de pertencimento, será a garantia de reprodução dessa cultura, preservando-a e sendo ele próprio um agente de transmissão simbólica para as gerações que o sucedem (Aulagnier, 1985).

É somente na medida em que esse pacto se dá de uma maneira "suficientemente boa", para usar a expressão de Winnicott, que se pode esperar que os sujeitos construídos nesse processo se percebam ligados por laços de pertencimento à totalidade social e se tornem indivíduos com uma integridade subjetiva razoavelmente bem sucedida. Aulagnier chama de "projeto identificatório" o processo pelo qual o indivíduo em vias de socialização produz um eu. A criança ao nascer é inteiramente dependente da mãe (ou de quem ocupe a função materna). A mãe é a garantia de sobrevivência física, é a oferta de um investimento libidinal primário indispensável à sobrevivência psíquica e é a guardiã, a mestra, a senhora absoluta da significação. É à mãe que compete designar com sentidos o que ainda é para o bebê uma experiência estésica amorfa, informulada. É ela quem vai oferecer os primeiros índices de discriminação e classificação do mundo, do meio ambiente. E um dos primeiros índices é justamente a separação entre o bebê e ela própria, a definição de limites entre a individualidade que é o bebê e o resto do mundo. Entretanto, esse lugar de 'senhora absoluta da significação' deve ser deslocado para que o bebê possa levar adiante o processo de diferenciação de si próprio. Isto só pode ser alcançado na medida em que a instância paterna intervenha, fazendo valer a noção de que as significações que a mãe oferece à criança não são absolutas, e têm origem em uma ordem que a transcende e da qual ela é apenas porta-voz: a instância da lei do pai, que é também - como afirma a autora - a lei dos pares. Só quando, rompendo com a simbiose inicial com a mãe, a criança começa a se organizar subjetivamente em torno de enunciados identificatórios que a predicam, que a qualificam de modo singular diante dos demais, é que se pode falar do início do projeto identificatório - a própria essência do eu.

O eu, portanto, existe no início como um nome, uma idéia, uma imagem no desejo dos pais, uma projeção de indivíduos que antecipam a chegada 
de mais um semelhante. Ele existe como possibilidade antecipada e desejada pelos eus já existentes. Pela repetição, vai paulatinamente tornando 'seus' esses ditos e enunciados sobre si próprio, veiculados pelos porta-vozes que lhe transmitem as significações sobre si e sobre o mundo. Uma vez ultrapassado o momento inicial, progressivamente entra em cena um agente, um 'enunciante'. Se de início ele depende de que sua existência e seu futuro estejam reafirmados na palavra dos outros significativos para ele, aos poucos vai se apropriando da função própria à atividade do eu, a de contar, para si e para os outros, as narrativas nas quais ele se revela com uma singularidade. É nesse momento, que o mergulho na temporalidade (e na incerteza, na imprevisibilidade, na precariedade) da vida psíquica vai configurar o eu como devir, como 'identidade' em constante processo de atualização. O eu se mostra como um "centro de gravidade narrativa”, como disse Daniel Dennett, uma ficção necessária como dizemos em psicanálise, uma narrativa construída na interação com outros eus, com o meio ambiente cultural e físico que o cerca, com seu próprio passado, e com as antecipações que faz acerca de seu futuro.

Compreender o eu dessa maneira é vê-lo como um feixe e um fluxo complexos de imagens identificatórias que organizam aquilo que percebemos com uma identidade mais ou menos estável a cada momento da existência. Significa também perceber no interior mesmo de seu funcionamento os pólos da identidade e da diferença. Pode-se afirmar isso lembrando que a existência do eu como uma narrativa de si que se desdobra supõe a preservação de um sentimento de identidade, ou 'ipseidade', que é corroborado pelas experiências inscritas na narrativa. Afinal, pluralidade identificatória não tem nada a ver com personalidade múltipla (nesta a condição patológica despedaça a narrativa do eu em enredos que não apenas não se relacionam como se excluem). Por outro lado, as aspirações identificatórias que projetam no futuro um eu diferente e o processo constante de reapropriação do passado em função de exigências presentes faz com que a afirmação de uma identidade do eu implique concomitantemente um movimento de diferenciação de si para si mesmo.

Nada garante em princípio a preservação do eu no tempo. Quem quer que tenha experimentado alguma vez angústia ou depressão compreende a afirmação imediatamente. É enorme a necessidade de encontrar meios pelos quais a precariedade e o desamparo que caracterizam a vida subjetiva sejam aliviados e produzam um sentimento de estabilidade e preservação em um meio de mudanças inevitáveis provocados pelo acaso, por um ambiente indiferente, ou simplesmente pelo tempo. Para que isso seja alcançado é indispensável que certas referências simbólicas sejam preservadas da precariedade e transitoriedade. É preciso que certas aspirações encontrem plausibilidade en- 
tre os pares, que as reconheçam como legítimas e realizáveis. É necessário que a experiência de si encontre algum grau de coerência com os enunciados e discursos que organizam o mundo de possibilidades compartilhadas. É importante que determinadas lembranças do passado, que funcionam como esteio de imagens do eu prazerosas e valorizadas, não se desfaçam sob a injunção de experiências traumáticas do presente.

Ora, uma das formas mais importantes que os humanos têm de enfrentar a experiência da precariedade, da imprevisibilidade que caracteriza a vida, é o investimento no futuro. A possibilidade de imaginar um futuro que não seja a repetição do passado, um futuro mais generoso e seguro do que o presente, é algo vital para o funcionamento do eu. Por mais estreitas que sejam as possibilidades do momento, a manutenção dessa capacidade preserva um significado para o presente e organiza a experiência do eu em direção a um horizonte mais aberto e mantém uma saída - por mais improvável que seja - para os conflitos e o sofrimento. Mesmo quando a sobrevivência física do indivíduo se encontra fortemente ameaçada, senão efetivamente condenada, é na antecipação de um futuro melhor para os filhos, os compatriotas, ou as próximas gerações humanas que o eu encontra esteio para se preservar e não se dissolver na angústia ou na indiferença total.

Essa característica do funcionamento do eu é fundamental para o projeto democrático. É claro que qualquer sociedade depende da existência de um futuro antecipável. No entanto, é preciso notar que a própria noção de futuro varia em contextos sócio-históricos diferentes. Em sociedades tradicionais hierárquicas, a noção de futuro está comprometida com uma visão do tempo que não privilegia o sentido de linearidade, nem a idéia de construção. O investimento no futuro pode ganhar a forma de 'reafirmação', por meio do resgate da tradição em processo de corrupção no presente, e não de invenção ou criação. Ou ainda, em sociedades fortemente regidas por utopias religiosas, o futuro pode estar identificado com alguma outra esfera que não a terrena, ou com uma escala de tempo medida não por gerações mas por períodos de tempo inimagináveis para os humanos. Quando um hindu tradicional pensa no futuro, sua escala é a de incontáveis reencarnações. Nas sociedades modernas o projeto democrático se apresenta em um horizonte laico, incrustado em uma experiência social do tempo que percebe o futuro como imprevisível, aberto à ação humana, como um espaço de criação do inimaginado, do inteiramente novo. Nessas circunstâncias, a possibilidade de investir o futuro é indispensável. Sem o exercício dessa capacidade não se criam cidadãos. Consumidores, com certeza. Contribuintes, talvez. Mas cidadãos, não. 
Como é possível se depreender facilmente, porém, essa capacidade de investir o futuro, e nessa operação exercer seu poder normativo, não pode ser uma atividade autônoma do eu, completamente independente das condições que cercam o seu 'projeto identificatório', ou seu processo constante de construção de si. Isso significa que a realidade social na qual os sujeitos se encontram pode facilitar ou, ao contrário, contribuir para o engessamento da atividade essencial do eu. Ou seja, a estrutura das relações sociais e a força do imaginário social que compõem o cenário no qual o eu circula determinam - em alguma medida (embora não de modo direto nem exclusivo) - o espectro de possibilidades, o grau de plausibilidade a que seus investimentos podem aspirar.

\section{Desigualdade e Hierarquia: o caso brasileiro}

O Brasil mostra certas peculiaridades que nenhum outro país do mundo, no momento, apresenta. É uma das mais poderosas economias e está entre os países de menor 'desenvolvimento humano'. Seu desempenho em termos distributivos é um dos piores do planeta. Sua concentração de renda é vergonhosa, assim como os índices de doenças da miséria, como a hanseníase, esquistossomose, malária, chagas e tuberculose. Único país do mundo com uma extensão territorial tão imensa e com uma única língua e cultura, cultiva, entretanto, desigualdades sociais e regionais tão brutais que impõem verdadeiras fronteiras internas. Não tivemos o racismo como ideologia oficial, mas ostentamos um verdadeiro apartheid social. Não temos entre nós a pulverização de etnias, nações ou comunidades lingüísticas ou religiosas que acendem fogueiras em tantos pontos do mundo. No entanto, abismos econômicosociais dividem parcelas da população, como se houvesse de fato mais de um país no mesmo território.

Há muitos países no mundo de hoje que impõem a grandes parcelas de suas populações uma vida de privações e dificuldades. Há muitos países pobres, incapazes de solucionar problemas básicos da população. Mas o Brasil não é pobre como a sua população é. O Brasil é basicamente injusto, desigual. Há muitos países - pobres ou não - nos quais o princípio da desigualdade prevalece sobre o da igualdade. Ainda hoje, nos países de cultura predominantemente tradicional e hierárquica, a igualdade entre todos os humanos está longe de ser um preceito admitido, mesmo legalmente. Basta olhar o que se passa nos países em que o fundamentalismo islâmico tomou o poder ou está estabelecido há algum tempo: a maioria das mulheres está condenada ao 'chador', à obediência absoluta e à extirpação do clitóris. 
$\mathrm{Na}$ sociedade indiana, apesar de o sistema de castas ter sido abolido oficialmente desde 1948, sua presença na cultura ainda é fortíssimo. Na vida fora dos corredores oficiais, os párias continuam sem olhar nos olhos dos passantes - pois os seus olhos contaminam aqueles a quem fitam. Seu toque é impuro, mesmo sua sombra é impura.

Mas o que diferencia de forma decisiva esses países de tradição hierárquica e o Brasil é que, no nosso caso - ao contrário do que ocorre com os demais -, nada temos que justifique 'nossa' hierarquia. Um pária indiano hindu tem uma explicação para sua condição: o determinismo cármico, que lhe oferece a oportunidade de, nesta encarnação, elevar-se espiritualmente e ascender a melhores condições em outras vidas. $\mathrm{O}$ manto religioso, matriz fundamental de significação para a existência pessoal, organiza o que para nós seria um absurdo em uma condição carregada de sentido. Muitas mulheres imigrantes de origem islâmica reivindicam o respeito a práticas e tradições de sua religião em países europeus cujas leis e culturas as consideram inaceitáveis. É claro que, tanto no caso indiano quanto no caso do fundamentalismo islâmico, há os que se insurgem contra essas regras e normas culturais. Mas o ponto importante é que essa forma de tratar os desiguais encontra alguma justificação, alguma razão de ser. Pode-se ser contra ou a favor da justificação, mas ela existe, e é por todos reconhecida. É um campo de significações que organiza o mundo de um determinado modo. Como qualquer outro, promove adesões e suscita oposição. Só não se pode dizer que há um sem-sentido, um vazio de significação na produção e na reprodução dessas desigualdades.

É justamente essa ausência que encontramos em 'nossa' hierarquia. Ela é violenta e nada a sustenta, exceto o cinismo dos donos do poder. O Brasil é, do ponto de vista jurídico-formal, uma democracia. Todos são iguais perante a lei, cidadãos com direitos e deveres iguais. Mas a realidade experimentada no cotidiano mostra uma realidade muito diferente. Muita coisa explica a miséria absoluta, o 'jeitinho', o apadrinhamento, a benevolência da lei para com os brancos e de colarinho e gravata, a fome cíclica no sertão, a explosão de favelas etc. (Da Matta, 1981). Mas não há nada que 'justifique' essas expressões brutais de desigualdade. São simplesmente a evidência da indiferença absoluta com que são tratados os irrelevantes. Estes se vêem às voltas com uma situação paradoxal: em um mundo oficialmente de iguais, são tratados como peças fora do jogo. Quando se voltam para o universo simbólico, no qual deveriam encontrar pontos de apoio para a construção de uma imagem à qual possam se identificar, encontram um espelho que não lhes devolve imagem alguma. 
Esse contraste entre a hierarquia tradicional de outras culturas e a desigualdade real e ilegítima de nossa sociedade já traria bons motivos de reflexão para as injunções que sofrem os sujeitos submetidos a esse 'descarte simbólico’ em nosso país. Certamente não se podem compreender muitos dos fenômenos complexos que infernizam a vida de nossas metrópoles, como a violência urbana e a fragilidade de nossas práticas democráticas, sem a consideração desse tipo de fator. $O$ quadro se torna mais preocupante ainda quando associamos a esse traço estrutural da sociedade brasileira o cenário que descrevemos no início, que vem se delineando nas últimas décadas, e que resulta em outro processo, globalizado, de produção de exclusão. Se estivermos de acordo com as conclusões acerca da importância axial do investimento no futuro como elemento que sustenta o eu capaz de agência e promessa, temos boas razões para nos ocuparmos com o problema da constituição do projeto democrático no Brasil. Sem o exercício da cidadania no cotidiano, realizado por sujeitos capazes de pensar o futuro como um horizonte de possíveis, onde as promessas de hoje quanto à realização de ideais solidários não esteja fadada à frustração permanente, não há como imaginar uma democracia ganhando corpo. Não serão decisões econômicas, nem desenvolvimentos tecnológicos, nem ampliação de faixas de consumidores que nos levarão mais perto da realização desse projeto. O terrível hoje é que se pode perfeitamente pensar uma economia forte e competitiva, instituições democráticas formais funcionando sem solavancos e, simultaneamente, uma população inteira de nãocidadãos mergulhado no limbo civil.

Importa salientar que é a esse esvaziamento da dimensão do futuro que podemos associar não apenas grande parte do impasses descritos, mas também algumas das estratégias a que são levados os sujeitos mutilados de seu próprio poder de desejar o futuro. Uma das saídas é a submissão. Submeter-se é acomodar-se às regras tais como elas se apresentam, justificar-se invocando a impotência ou a inutilidade de qualquer tentativa de crítica. É o império da "razão cínica" (Costa, 1988). O consumo de drogas de todo tipo, a ideologia da prosperidade material e a aquisição compulsiva e ostentatória de objetos funcionam cada vez mais como mecanismos por meio dos quais os sujeitos modelam as identidades. Afundados em uma cultura em que a expansão narcísica ilimitada do eu não mais encontra as barreiras simbólicas dos ideais coletivos, os indivíduos precisam ancorar suas identidades em algo um pouco mais 'sólido'. O fundamentalismo religioso de todos os matizes e as identidades fundadas em itens 'naturais' (etnias, cor da pele, sexo ou orientação sexual etc.) são exemplos desse tipo de solução. Outra forma de submissão, crescen- 
te aos nossos olhos, é a da violência banalizada. Para os que participam da festa, ela parece fazer parte das regras do jogo. Para os excluídos, ela é apenas um recurso para arrancar nacos do que parece ser o banquete do qual foram expulsos. Quando não há nada a ganhar, não há nada a perder. Matar por causa de um tênis usado não significa grande coisa.

O quadro no fim do século é certamente menos auspicioso do que o do início. Havia mais generosidade na imaginação do futuro e mais esperanças na possibilidade de realizá-lo. Apostas altas foram feitas, e o jogo terminou antes do previsto. No momento, o sentimento de crise prevalece. Mas quer para os indivíduos, quer para a sociedade, a solução é clara: não há saída exceto a retomada da aspiração utópica e a ampliação e aprofundamento do projeto democrático. Foi no seu interior que se construiu o maior dos feitos da espécie humana: a bela e improvável imagem de uma sociedade e de um ser humano marcados pelo amor à liberdade e pela prática da solidariedade.

\section{REFERÊNCIAS BIBLIOGRÁfICAS}

ARENDT, H. A Condição Humana. Rio de Janeiro: Forense-Universitária, 1981.

AULAGNIER, P. Os Destinos do Prazer. Rio de Janeiro: Imago, 1985.

CASTORIADIS, C. A Instituição Imaginária da Sociedade. Rio de Janeiro: Paz e Terra, 1982.

CASTORIADIS, C. Socialismo ou Barbárie. São Paulo, Brasiliense, 1983.

CASTORIADIS, C. Feito e a Ser Feito. Rio de Janeiro: DP\&A, 1999.

COSTA, J. F. Narcisismo em tempos sombrios. In: BIRMAN, J. (Org.) Percursos na História da Psicanálise. Rio de Janeiro: Taurus, 1988.

Da MATTA, R. Carnavais, Malandros e Heróis. Rio de Janeiro: Zahar, 1981.

DUMONT, L. Homo hierarquicus: Paris: Mouton, 1978.

DUMONT, L. O Individualismo: uma perspectiva antropológica da ideologia moderna. Rio de Janeiro: Rocco, 1985.

KURTZ, R. Os Últimos Combates. Petrópolis: Vozes, 1997.

SENNETT, R. A Corrosão dos Ideais. Rio de Janeiro: Jorge Zahar, 1999. 